\title{
HARGA DIRI DAN KEMATANGAN KARIER PADA MAHASISWA TINGKAT AKHIR
}

\author{
SELF ESTEEM AND CAREER MATURITY IN FINAL-YEAR \\ UNDERGRADUATE STUDENTS
}

\author{
Kristiana Dwi Purnasari ${ }^{1}$, Sri Muliati Abdullah ${ }^{2}$ \\ ${ }^{12}$ Universitas Mercu Buana Yogyakarta \\ ${ }^{1}$ kristiana.dwipurnasari@gmail.com, ${ }^{2}$ muliatiyogya@gmail.com
}

\begin{abstract}
Abstrak
Penelitian ini bertujuan untuk mengetahui hubungan antara harga diri dengan kematangan karier pada mahasiswa S1 tingkat akhir di Yogyakarta. Hipotesis yang diajukan dalam penelitian ini adalah terdapat hubungan positif antara harga diri dengan kematangan karier pada mahasiswa S1 tingkat akhir. Subyek penelitian ini yaitu mahasiswa S1 tingkat akhir di Yogyakarta, dengan usia 21-24 tahun dengan jumlah 101 orang. Metode pengumpulan data penelitian ini yaitu dengan menggunakan metode skala yakni skala Harga Diri dan skala Kematangan Karier. Analisis data menggunakan korelasi product moment. Hasil analisis data pada penelitian ini menunjukkan nilai $\mathrm{r}=0,628(\mathrm{p}<0.05)$. Berdasarkan hasil korelasi tersebut, maka dapat disimpulkan bahwa terdapat hubungan positif antara harga diri dengan kematangan karier pada mahasiswa S1 tingkat akhir di Yogyakarta, sehingga hipotesis yang diajukan dapat diterima. Berdasarkan analisis data diketahui bahwa variabel harga diri memberikan sumbangan sebesar $\mathrm{R}^{2}=0,394$ atau 39,4\% terhadap kematangan karier dan $60,6 \%$ dipengaruhi oleh faktor lain.
\end{abstract}

Kata kunci : Harga diri, kematangan karier, mahasiswa

\begin{abstract}
This research aims to determine the relationship between self-esteem and career maturity in finalyear undergraduate students in Yogyakarta. The hypothesis proposed in this study is that there is a positive relationship between self-esteem and career maturity in final-year undergraduate students. The subjects of this study were final-year undergraduate students from several universities in Yogyakarta, within the age of 21-24 years with a total of 101 people. The data collection method of this research is using the scale method of self-esteem scale and the career maturity scale. The data analysis uses the product moment correlation. The results of the data analysis in this study showed the value of $r=0.628$ ( $p<0.05)$. Based on the results of this correlation, it can be concluded that there is a positive relationship between self-esteem and career maturity in final-year undergraduate students at Yogyakarta, so the proposed hypothesis can be accepted. Based on the data analysis, it is known that the self-esteem variable contributes $R^{2}=0,394$ or $39,4 \%$ towards career maturity and $60,6 \%$ is influenced by other factors.
\end{abstract}

Keywords: Self-esteem, career maturity, undergraduate students.

\section{PENDAHULUAN}

Permasalahan mengenai ketenagakerjaan semakin hari semakin kompleks. Permasalahan tersebut salah satunya dikarenakan semakin banyaknya pengangguran intelektual di Indonesia dari tahun ke tahun. Pengangguran intelektual merupakan lulusan 
perguruan tinggi, baik diploma maupun sarjana S1 yang belum memiliki pekerjaan atau tidak bekerja. Pada bulan Februari 2016, Badan Pusat Statistik (BPS) mencatat bahwa jumlah penggangguran intelektual adalah sebagai berikut :

Tabel 1. Jumlah lulusan Diploma dan Sarjana S1

\begin{tabular}{ccc}
\hline & Tahun Lulus 2014 & Tahun Lulus 2016 \\
\hline Diploma & 193.517 orang & 249.362 orang \\
Sarjana S1 & 495.143 orang & 695.304 orang \\
\hline
\end{tabular}

(Sumber : Badan Pusat Statistik, 2016)

Data tersebut memperlihatkan adanya peningkatan yang signifikan dari jumlah pengangguran intelektual tahun 2014 dibandingkan dengan data yang dihimpun BPS pada tahun 2016 (Badan Pusat Statistika, 2016). Dampak dari banyaknya jumlah lulusan sarjana S1 adalah pada persaingan memperoleh pekerjaan. Persaingan dalam mencari pekerjaan tidak selaras dengan lulusan sarjana S1 yang tinggi, dengan daya serap lapangan pekerjaan yang rendah, maka memunculkan banyaknya penggangguran (https://student.cnnindonesia.com/edukasi, 2017)

Karier merupakan salah satu unsur penting dalam kehidupan seseorang. Karier tidak hanya berkaitan dengan aspek fisik, tetapi juga aspek psikologi individu sehingga individu perlu untuk merencanakan dan mempersiapkan karier sedini mungkin. Melalui perencanaan karier yang matang individu berusaha untuk mendapatkan karier yang sesuai dengan bakat, minat, nilai dan kemampuan yang dimiliki. Pada masa dewasa awal mempunyai tugas perkembangan salah satunya karier (Hurlock, 1990). Individu berusia dewasa awal adalah seseorang yang duduk di bangku mahasiswa S1 tingkat akhir. Sesuai dengan subjek dalam penelitian ini adalah mahasiswa S1 tingkat akhir di beberapa kampus di Yogyakarta. Hal ini karena masa dewasa awal seseorang sudah dituntut untuk mempersiapkan karier dan memilih karier yang akan dituju dengan bijaksana, sehingga remaja dapat mempersiapkan diri untuk mencapai karier. Kematangan karier penting dimiliki oleh seorang yang berada dalam fase dewasa awal, karena harus mempersiapkan karier dengan matang (Hervy, 2015). Selain itu, ketika seseorang berkarier dengan bekerja yang dapat berkontribusi pada lingkungan sosial yang lebih luas, akan muncul harga diri yang lebih besar, kepuasan hidup yang lebih tinggi dan meningkatkan keberartian personal serta koneksi sosial (McIntosh, 2000).

Sesuai pendapat Hurlock (1990) di atas, mahasiswa S1 tingkat akhir seharusnya telah menentukan pilihan dalam berkarier, sehingga mahasiswa S1 tingkat akhir sudah mulai 
untuk melatih diri sesuai dengan hal yang diperlukan pada karier yang akan dipilihnya. Mahasiswa akan merasa lebih puas dengan keputusan dalam memilih karier yang relevan dengan minatnya. Menurut Gonzalez (2008) kematangan karier merupakan kematangan individu yang disesuaikan dengan tahap perkembangannya dengan melihat kesesuaian tahap individu dengan usia kronologisnya. Dalam kematangan karier tersusun berdasarkan lima aspek kematangan karier, yaitu perencanaan karier, sumber-sumber eksplorasi, informasi, pengambilan keputusan, berorientasi pada realitas (Gonzalez, 2008). Variabel kematangan karier dalam penelitian ini disusun berdasarkan kelima aspek tersebut.

Pada kenyataannya, masih banyak mahasiswa S1 tingkat akhir yang merasa bingung terkait hal yang akan mereka kerjakan setelah lulus dari perguruan tinggi. Hasil survey menunjukan bahwa sumber eksplorasi dan informasi yang dimiliki oleh mahasiswa S1 tingkat akhir masih rendah, yaitu 63,5\% (Hervy, 2015). Hal ini menunjukkan bahwa mahasiswa S1 tingkat akhir kurang dapat melakukan eksplorasi terhadap dirinya sendiri dalam hal karier dan pencarian informasi yang menunjang kariernya.

Data lapangan sebelum dilakukan penelitian menunjukkan bahwa dari wawancara yang dilakukan pada tanggal 20 April 2017, terdapat 8 dari 12 mahasiswa belum merencanakan kariernya, yang ditunjukkan dengan belum mempersiapkan apa yang akan dilakukan di dunia kerja, merasa belum perlu mencari tahu informasi tentang pekerjaan yang akan ditujunya, belum merasa perlu untuk mengeksplorasi diri untuk menentukan pekerjaannya nanti, dan belum dapat mengambil keputusan sendiri dalam memilih kariernya, belum mempunyai inisiatif untuk mencari informasi dan mengembangkan kemampuannya untuk memasuki dunia pekerjaan. Rasa bingung, kurangnya keterampilan dan pengalaman yang dirasakan cerminan dari kekurangmatangan karier.

Menurut Super (Savickas, 2001), kematangan karier dipengaruhi oleh dua faktor, yaitu faktor eksternal dan internal. Faktor eksternal dipengaruhi oleh keluarga, latar belakang sosial ekonomi, gender, teman sebaya, lingkungan dan sekolah. Faktor Internal yaitu dipengaruhi oleh intelegensi, bakat, minat, kepribadian, harga diri dan nilai. Peneliti memilih harga diri karena harga diri merupakan penilaian terhadap diri tentang keberhargaan diri yang diekspresikan melalui sikap-sikap yang dipercayai oleh individu. Seseorang yang memasuki dewasa awal memiliki harga diri cukup tinggi, akan yakin dapat mencapai karier yang diinginkan. Pada saatnya keyakinan itu yang akan memotivasi individu tersebut untuk sungguh-sungguh mencapai karier yang diinginkan (Amy, 2015)

Kematangan karier penting dimiliki oleh seorang yang telah masuk dalam fase dewasa awal karena harus mempersiapkan karier dengan matang (Hurlock, 1990). Mahasiswa S1 
tingkat akhir akan memasuki dunia pekerjaan, sehingga diharapkan mampu memilih dan mempersiapkan karier. Seseorang yang memiliki kematangan karier yang tinggi merupakan seseorang yang siap bekerja dalam segi psikologis. Kematangan karier dalam perkembangannya banyak dipengaruhi oleh faktor dari dalam maupun dari luar diri individu tersebut. Faktor yang berasal dari luar diri individu disebut faktor eksternal yang meliputi keluarga, lingkungan sekolah, realitas dan proses pendidikan. Faktor yang berasal dari dalam diri individu disebut faktor internal yang meliputi, intelegensi, minat, bakat, kepribadian, harga diri dan nilai. Artinya beberapa faktor yang berasal dari luar ataupun dalam diri individu memiliki peranan penting dalam kematangan karier. Salah satu faktor penting yang berhubungan dengan kematangan karier yaitu harga diri.

Dalam penelitian Yulianti, Hardjono, \& Nugroho (2013) yang berjudul "Hubungan antara harga diri dan motivasi berprestasi pada siswa kelas XI SMK N 3 Surakarta" terdapat sumbangan efektif harga diri terhadap kematangan karier pada remaja sebesar 20,295\% dan sumbangan efektif motivasi berprestasi terhadap kematangan karier pada remaja sebesar $21,405 \%$. Hal ini berarti masih terdapat 58,3\% faktor lain yang mempengaruhi kematangan karier pada remaja selain harga diri dan motivasi berprestasi. Dalam penelitian Amy (2015) yang meneliti siwa SMK 2 Depok, Sleman, Yogyakarta kelas XI menyatakan bahwa ada hubungan yang positif dan signifikan antara harga diri dengan kematangan karier. Nilai tersebut didukung dengan besarnya sumbangan efektif yang diberikan variabel harga diri dengan kematangan karier sebesar 41,6\%, sedangkan sisanya 59,4\% dipengaruhi oleh faktor lain. Kematangan karier penting dimiliki oleh remaja, karena remaja harus memilih dan mempersiapkan karier dengan matang. Siswa SMK akan memasuki dunia pekerjaan, sehingga diharapkan mampu memilih dan mempersiapkan karier. Kematangan karier dipengaruhi oleh beberapa faktor dan salah satu faktor yang penting adalah harga diri. Remaja yang memiliki harga diri yang tinggi akan termotivasi untuk mempersiapkan kariernya dengan baik dan akan mencapai pekerjaan sesuai dengan yang diinginkan. Sebaliknya, remaja yang memiliki harga diri yang rendah akan merasa tidak mampu dan tidak berharga. Hal ini yang dapat melemahkan upaya remaja tersebut dalam mempersiapkan karier dengan baik (Amy, 2015).

Berdasarkan dari beberapa penelitian tersebut, dapat dilihat bahwa penelitian mengenai hubungan harga diri dengan kematangan karier menunjukan hasil yang sama, tetapi peneliti ingin melihat apakah hal ini juga memiliki hasil yang sama jika diterapkan pada mahasiswa S1 tingkat akhir. Peneliti memilih subyek mahasiswa S1 tingkat akhir karena pada usia dewasa awal, seharusnya sduah berorientasi menuju ke dunia pekerjaan, 
tetapi masih banyak yang belum memikirkan hal tersebut. Maka dari itu, peneliti akan meneliti hubungan antara kedua variabel tersebut pada mahasiswa S1 tingkat akhir di beberapa universitas di Yogyakarta.

Menurut Gonzalez (2008), kematangan karier merupakan kematangan individu yang disesuaikan dengan tahap perkembangannya dengan melihat kesesuaian antara tahap kematangan individu dengan usia kronologisnya. Untuk dapat memahami lebih jauh mengenai kelima dimensi tersebut, maka akan dijelaskan sebagai berikut :

a. Perencanaan karier (Careers planfulness)

Adalah kesadaran individu bahwa dirinya harus membuat pilihan pendidikan dan karier, serta mempersiapkan diri untuk memasuki karier tertentu. Perencanaan karier sangat berpengaruh terhadap kematangan karier pada diri invidu. Mereka akan melakukan perencanaan karier untuk waktu dekat, maupun waktu yang masih panjang. Mereka akan merencanakan karier untuk masa depan yang masih jauh, masa depan yang lebih dekat, dan masa kini atau masa yang sedang dijalani.

b. Sumber-sumber eksplorasi (Resources for exploration)

Adalah proses yang menunjukan individu mengadakan atau menggali segala informasi mengenai dunia kerja yang diperlukannya dari berbagai sumber yang ada. Kematangan karier berkaitan dengan tahap pengeksplorasian. Individu dapat melakukan eksplorasi pada dirinya, melalui berkonsultasi dengan orang lain, mencari sumber-sumber yang berkaitan, dan berpartisipasi aktif dalam suatu kegiatan yang menunjang karier yang akan dituju individu tersebut.

c. Informasi (Information)

Adalah yaitu menilai pengetahuan tentang pendidikan dan informasi perkerjaan atau karier. Informasi menjadi hal yang penting untuk menunjang kematangan karier. Banyak cara untuk dapat memperoleh informasi, yaitu melalui pendidikan, kualifikasi yang dibutuhkan, dan tersediannya kesempatan yang lebih maju.

d. Pengambilan keputusan (Decision making)

Adalah individu mengetahui segala sesuatu yang harus di pertimbangkan dalam membuat pilihan pendidikan dan karier, kemudian membuat pilihan pekerjaan sesuai dengan kemampuannya. Kematangan karier berhubungan erat dengan pengambilan sebuah keputusan. Dalam memutuskan suatu hal, individu akan berpegang pada prinsip yang dimiliki. Pelatihan-Pelatihan yang telah dijalani oleh individu dapat pula menjadi pertimbangan yang penting bagi individu dalam melakukan pengambilan keputusan. 
e. Berorientasi pada realita (Reality orientation)

Adalah individu mengetahui orientasi tentang pilihan karier yang akan dipilih sehingga berusaha meningkatkan kemampuan diri agar sesuai dengan karier yang telah dipilih. Kematangan karier pada individu senantiasa berorientasi pada realita. Hal itu dapat tercermin dari diri individu, yaitu individu memiliki pengetahuan yang baik akan dirinya, individu mampu berpikir dengan realistik, individu mampu menunjukan sikap yang konsisten, dan individu memiliki pengalaman kerja yang memadai (Gonzalez,2008).

Peneliti menggunakan aspek yang diungkap oleh Super (dalam Gonzalez, 2008) yaitu perencanaan karier (careers planfullness), sumber-sumber ekplorasi (resources for exploration), informasi (information), pengambilan keputusan (decision making), dan berorientasi pada realita (reality orientation).

Menurut Super (Savickas, 2001) mengemukakan kematangan karier dalam perkembangannya banyak dipengaruhi oleh faktor dari dalam maupun dari luar diri, diantaranya sebagai berikut :

a. Faktor Internal

1) Intelegensi, merupakan kemampuan yang dimiliki seseorang secara menyeluruh, salah satunya kemampuan dalam pengambilan keputusan. Intelegensi turut berperan aktif dalam menentukan keberhasilan individu menentukan pilihan dan keputusan kariernya.

2) Bakat, dalam perkembangan karier, individu dapat mengetahui bahwa dirinya cocok di suatu bidang dari faktor bawaan atau potensi yang dimilikinya.

3) Minat, merupakan kecenderungan pada sesuatu yang menarik hati. Begitu juga jika disangkutkan dengan karier, tentu saja individu memainkan peran minat dalam ketertarikannya terhadap pemilihan suatu jurusan atau pekerjaan, dengan minat sesuatu akan menjadi lebih baik untuk pekerjaan.

4) Kepribadian. karakteristik seseorang merupakan faktor pendukung seseorang diaktakan berhasil dalam menyelesaikan tugas perkembangan kariernya, misalnya dari tes kepribadian seseorang dapat mengetahui kategori pekerjaan yang sesuai dengan kepribadiannya

5) Harga diri. Harga diri merupakan faktor penting dalam menentukan karier individu, karena dapat menilai sejauh mana dirinya merasa pantas pada sebuah jabatan, individu melihat dari perilaku yang telah dilakukan sendiri, tetapi juga dipengaruhi oleh hasil 
interaksinya dengan orang-orang penting dilingkungannya serta dari sikap penerimaan, penghargaan dan perlakuan orang lain terhadap dirinya.

6) Nilai. Seseorang beranggapan suatu jabatan itu bernilai tinggi atau rendah tergantung penilainnya dalam memandang suatu pekerjaan yang ingin dicapainya. Oleh karena itu nilai dapat menjadi faktor yang penting dalam memilih suatu pekerjaan.

b. Faktor Eksternal

1) Keluarga. Dari lingkungan keluargalah individu dapat menentukan keberhasilan kariernya, kareana ada beberapa orang disana yang dapat menjadi inspirasi ataupun didikan yang mengembangkan dirinya untuk menentukan pilihan karier.

2) Latar Belakang Sosial Ekonomi. Hal ini mempengaruhi dalam mengambil keputusan. Begitu juga dalam penentuan kariernya, latar belakang sosial ekonomi turut menjadi bahan pertimbangan seseorang dalam menentukan kariernya.

3) Gender. Dalam memandang sebuah jurusan atau pekerjaan beberapa dari individu melihatnya dan sudut pandang yang mengkualifikasikan pekerjaan maka yang lebih pantas dikerjakan laki-laki dan mana yang pantas dikerjakan oleh seorang perempuan.

4) Teman Sebaya. Hubungan teman sebaya juga mempengaruhi individu dalam penentuan pilihan kariernya, tidak jarang orang yang labil mudah dipengaruhi dalam bujukan teman sebaya untuk mengikuti jejaknya atau menjadi pilihan yang tepat karena merasa lebih nyaman dengan lingkungan yang lebih banyak teman seusianya ataupun sebaliknya.

5) Lingkungan Sekolah. Sekolah dapat mempengaruhi segala informasi pendidikan yang diberikan oleh guru dan patut untuk dikembangkan dalam kehidupan di masa depan.

Peneliti memilih untuk menggunakan faktor yang dijelaskan menurut Super (Savickas, 2001) yang meliputi faktor internal dan eksternal, secara khusus yang dijelaskan pada faktor internal yang meliputi, intelegensi bakat, minat, kepribadian, harga diri dan nilai. Faktor yang peneliti pilih yaitu harga diri. Harga diri dapat dipahami sebagai hasil evaluasi individu terhadap dirinya sendiri yang diekspresikan dalam sikap terhadap diri sendiri. Evaluasi ini menyatakan suatu sikap penerimaan atau penolakan dan menunjukkan seberapa besar individu percaya bahwa dirinya mampu, berarti, berhasil, berharga menurut standart dan nilai pribadinya (Amy, 2015).

Aspek-aspek harga diri secara lebih rinci dikemukakan oleh Coopersmith (1987), yaitu :

a. Keberartian Diri (Significance), yaitu adanya kepedulian dan afeksi yang diterima individu dari orang lain. Hal itu membuat individu cenderung mengembangkan 
harga diri yang rendah atau negatif. Jadi, berhasil atau tidaknya individu memiliki keberartian diri dapat diukur melalui perhatian dan kasih sayang yang ditunjukkan oleh lingkungan.

b. Kekuatan Individu (Power). Kekuatan di sini berarti kemampuan individu untuk mempengaruhi orang lain, serta mengontrol atau mengendalikan orang lain, di samping mengendalikan dirinya sendiri. Apabila individu mampu mengontrol diri sendiri dan orang lain dengan baik maka hal tersebut akan mendorong terbentuknya harga diri yang positif atau tinggi, demikian juga sebaliknya. Kekuatan juga dikaitkan dengan inisiatif.

c. Kompetensi (Competence). Kompetensi diartikan sebagai usaha untuk mendapatkan prestasi yang baik, sesuai dengan tahapan usianya. Misalnya, pada remaja putra akan berasumsi bahwa prestasi akademik dan kemampuan atletik adalah dua bidang utama yang digunakan untuk menilai kompetensinya, maka individu tersebut akan melakukan usaha yang maksimal untuk berhasil di bidang tersebut. Apabila usaha individu sesuai dengan tuntutan dan harapan, itu berarti invidu memiliki kompetensi yang dapat membantu membentuk harga diri yang tinggi.

d. Kebajikan (Virtue), adalah ketaatan untuk mengikuti standart moral dan etika yang berlaku di masyarakat. Ketaatan individu terhadap aturan dalam masyarakat serta tidak melakukan tindakan yang menyimpang dari norma dan ketentuan yang berlaku di masyarakat akan membuat individu tersebut diterima dengan baik oleh masyarakat. Peneliti memilih untuk menggunakan aspek yang dijelaskan menurut Coopersmith (1987) yaitu keberartian diri (Significance), kekuatan individu (Power), Kompetensi (Competence), Ketaatan Individu dan Kemampuan Memberi Contoh (Virtue).

Keberartian diri akan membuat individu merasa dirinya berarti atau tidak untuk diri sendiri maupun lingkungan. Rasa keberartian hidup yang tinggi akan menyebabkan tumbuhnya kesadaran untuk merencanakan kariernya dan mempunyai bayangan masa depan kariernya cerah. Kariernya dipandang mampu menjadi sumber penghidupan dan kebahagiaanya, serta mampu memberi manfaat untuk orang lain. Aspek harga diri "kekuatan individu" dalam mempengaruhi orang lain, mengendalikan diri dan mengontrol orang lain berperan mengarahkan dirinya untuk menyiapkan karier di masa depan, menggali potensi diri dengan melakukan kegiatan-kegiatan yang menunjang kariernya. Selain itu, kompetensi menjadi faktor yang dapat menunjang karier karena menjadi modal penting dalam melakukan usaha yang maksimal dengan berpikir realistis dan konsisten pada pencapaian 
prestasi. Ketaatan individu pada aturan / ketentuan dan kemampuan untuk memberikan contoh panutan yang baik pada akhirnya akan mampu menjadi inspirasi yang baik bagi rekannya, termasuk dalam membangun dan mencapai puncak karier.

Berdasarkan uraian tersebut, maka dirumuskan hipotesis sebagai berikut teredapat hubungan positif antara harga diri dengan kematangan karier pada mahasiswa S1 tingkat akhir di beberapa perguruan tinggi di Yogyakarta.

\section{METODE}

Penelitian ini melibatkan subjek penelitian dengan karakteristik :

1. Berusia dewasa awal yaitu antara 21 hingga 24 tahun

2. Mahasiswa S1 tingkat akhir (semester 6 ke atas)

Teknik sampling yang digunakan adalah incidental sampling, yaitu teknik pengambilan sampel pada siapa saja yang secara kebetulan bertemu dengan peneliti.

Metode pengumpulan data yang dilakukan dalam penelitian ini adalah dengan menggunakan metode skala. Skala yang digunakan dalam penelitian ini adalah skala Kematangan Karier dan skala Harga Diri. Skala Likert digunakan untuk mengukur sikap, perilaku, pendapat dan persepsi seseorang atau kelompok tentang fenomena sosial. Pada penelitian ini metode penskalaan yang digunakan adalah Method of Summated Rating dari Likert. Dalam skala ini subyek diminta untuk memberi tanda pada salah satu dari empat pilihan jawaban yang tersedia yaitu Sangat Sesuai (SS), Sesuai (S), Tidak Sesuai (TS), Sangat Tidak Sesuai (STS). Skala Kematangan Karier pada mahasiswa S1 tingkat akhir di beberapa perguruan tinggi di Yogyakarta terdiri dari 20 aitem favorable dan 20 aitem unfavorable. Skala Harga Diri pada mahasiswa S1 tingkat akhir di beberapa perguruan tinggi di Yogyakarta terdiri dari 16 aitem favorable dan 16 aitem unfavorable.

Skala diujicoba pada tanggal 8 Juli - 18 Agustus 2017 dengan melibatkan 105 partisipan yang memenuhi kriteria karakteristik subjek. Hasil uji coba skala Kematangan Karier menunjukkan bahwa dari 40 aitem yang diujicobakan menghasilkan 32 aitem yang valid. Koefisien daya beda aitem skala kematangan karier berkisar antara 0,277 sampai dengan 0,620. Koefisien reliabilitas Cronbach Alpha setelah aitem yang gugur dikeluarkan, sebesar 0,897. Hasil uji coba skala Harga Diri menunjukkan dari 30 aitem yang valid menghasilkan 28 aitem yang valid. Koefisien daya beda aitem skala harga diri berkisar antara 0,287 sampai dengan 0,728. Koefisien reliabilitas Cronbach Alpha setelah aitem yang gugur dikeluarkan, sebesar 0,898 . 
Metode analisis yang digunakan dalam penelitian ini adalah korelasional. Penelitian korelasional adalah suatu metode untuk menyelidiki nilai-nilai dari dua variable dan menguji atau menentukan hubungan atau antar hubungan yang ada di antara mereka di dalam satu lingkungan tertentu (Silalahi, 2010). Uji Hipotesis yang digunakkan dalam penelitian ini adalah uji korelasi Product Moment dari Pearson menggunakan program bantuan SPSS for Windows 16.0.

\section{HASIL DAN PEMBAHASAN}

Data penelitian diperoleh dari 101 subjek yaitu mahasiswa S1 tingkat akhir di beberapa perguruan tinggi di Yogyakarta dengan rentang usia 21-24 tahun. Berdasarkan data dari penelitian yang terkumpul diperoleh skor empirik dan perhitungan skor hipotetik dari variabel kematangan karier dan variabel harga diri. Berikut tabel analisa statistik data penelitian :

Tabel 2. Analisa statistik data penelitian $(\mathrm{N}=101)$

\begin{tabular}{|c|c|c|}
\hline Analisa & Harga Diri & Kematangan karier \\
\hline Jumlah aitem skala & 30 & 32 \\
\hline Rentang skor hipotetik & $30-120$ & $32-128$ \\
\hline Rentang skor empirik & $66-114$ & $72-127$ \\
\hline Uji normalitas (uji KS-Z) & $\begin{array}{c}0,107 \text { dengan } \mathrm{p}=0,006 \\
(\mathrm{p}<0,05) \\
\text { (sebaran data tidak normal) }\end{array}$ & $\begin{array}{l}0,087 \text { dengan } p=0,057 \\
\quad(p>0,05) \\
\text { (sebaran data normal) }\end{array}$ \\
\hline Uji linieritas & \multirow{3}{*}{\multicolumn{2}{|c|}{$\begin{array}{l}\mathrm{F}=90,463 \text { dengan } \mathrm{p}=0,000(\mathrm{p}<0,050) \text { (hubungan kedua } \\
\text { variabel linier) } \\
\mathrm{r}=0,628(\mathrm{p}<0.05) \\
\text { ada hubungan yang sangat signifikan } \\
\mathrm{R}^{2}=0,394 . \text { Variabel harga diri berkontribusi atau memberi } \\
\text { sumbangan sebesar } 39,4 \% \text { terhadap variabel kematangan } \\
\text { karier }\end{array}$}} \\
\hline Uji korelasi product & & \\
\hline $\begin{array}{l}\text { moment } \\
\text { Koefisien determinasi }\end{array}$ & & \\
\hline
\end{tabular}

Keterangan : N = Jumlah sunjek penelitian; KS = Kolmogorov Smirnov

Sumber : Data olahan peneliti

Berdasarkan perhitungan data hipotetik skor variabel kematangan karier diperoleh skor minimum $32 \times 1=32$ dan skor maksimum sebesar 32 × $4=128$. Rerata hipotetik sebesar $((1 \times 32)+(4 \times 32)): 2=80$. Jarak sebaran hipotetik adalah $128-32=96$, dengan standar deviasi sebesar $(128-32): 6=16$. Dari skor variabel kematangan karier diperoleh data empirik yaitu skor minimum sebesar 72 dan skor maksimum sebesar 127 dengan ratarata sebesar 96,12 dan standar deviasi sebesar 9,754.

Berdasarkan perhitungan data hipotetik skor variabel harga diri diperoleh skor minimum $30 \times 1=30$ dan skor maksimum sebesar $30 \times 4=120$. Rerata hipotetik sebesar $((1$ $\mathrm{x} 30)+(4 \mathrm{x} 30)): 2=75$. Jarak sebaran hipotetik adalah $120-30=90$, dengan standar 
deviasi sebesar $(120-30): 6=15$. Dari skor variabel harga diri diperoleh data empirik yaitu skor minimum sebesar 66 dan skor maksimum sebesar 114 dengan rata-rata sebesar 87,88 dan standar deviasi sebesar 8,734 .

a. Uji Normalitas

Uji normalitas merupakan analisis yang dilakukan untuk mengetahui apakah sebaran masing-masing data variabel memenuhi sebaran data yang normal. Tujuan dari uji normalitas adalah untuk melihat sebaran data kematangan karier dan harga diri dalam penelitian ini terdistribusi normal atau tidak. Uji normalitas digunakan menggunakan teknik Kolmogorov-Smirnov. Pedoman yang digunakan dalam pengujian ini adalah jika $\mathrm{p}>0,05$ maka sebaran data dikatakan normal, dan jika $\mathrm{p}<0,05$ maka sebaran data dikatakan tidak normal (Safitri, 2014).

Hasil uji normalitas sebaran data variabel kematangan karier menunjukan nilai KS-Z sebesar 0,087 ( $\mathrm{p}>0,05)$. Hal tersebut menunjukan bahwa sebaran data kematangan karier mengikuti sebaran data normal. Hasil uji normalitas untuk data harga diri menunjukan nilai KS-Z sebesar 0,107 ( $<<0,05)$. Hal ini menunjukan sebaran data harga diri mengikuti sebaran data yang tidak normal.

Menurut Sugiyono (2010) data selalu diasumsikan normal karena pada umumnya fenomena yang terjadi mengikuti sebaran atau ditribusi normal. Asumsi ditribusi normal hanya sebagai sarana untuk mencapai tujuan penelitian, sehingga meskipun data tidak terdistribusi normal penelitian masih dapat dilanjutkan. Priyatno (2010) mengatakan bahwa data yang banyaknya lebih dari 30 maka dapat dikatakan terdistribusi dengan normal dan biasa disebut sampel besar. Data dalam penelitian ini menggunakan subjek sebanyak 101 subjek sehingga data dapat dikatakan terdistribusi normal.

b. Uji Linieritas

Uji linieritas dilakukan untuk mengetahui linieritas hubungan antara variabel bebas dengan variabel tergantung. Dalam penelitian ini uji linieritas dilakukan dengan menggunakan Test of Linierity. Kaidah untuk uji linieritas adalah apabila $\mathrm{p}<0,050$ maka hubungan antara variabel bebas dan variabel terikat merupakan hubungan yang linier. Apabila $p>0,050$ maka hubungan antara variabel bebas dan variabel terikat bukan merupakan hubungan yang linier (Safitri, 2014).

Hasil uji linieritas variabel data kematangan karier dan harga diri menunjukan nilai koefisien linier $\mathrm{F}=90,463$ dengan $\mathrm{p}=0,000(\mathrm{p}<0,050)$. Berdasarkan uraian data diatas dapat disimpulkan bahwa terdapat hubungan yang linier antara variabel kematangan karier 
dengan variabel harga diri. Artinya setiap perubahan yang terjadi pada satu variabel akan diikuti perubahan dengan besaran yang sejajar pada variabel lainnya (Azwar, 2004)

c. Uji Hipotesis

Setelah diketahui data yang diperoleh terdistribusi secara normal dan mempunyai hubungan yang linier, maka dapat dilakukan uji hipotesis untuk mengetahui ada atau tidaknya hubungan antara harga diri dengan kematangan karier. Dalam penelitian ini, teknik analisis data yang digunakan adalah korelasi Product Moment dari Pearson, untuk menguji hubungan antara variabel $\mathrm{X}$, yaitu variabel harga diri dengan variabel $\mathrm{Y}$, yaitu variabel kematangan karier. Taraf signifikansi yang digunakan sebesar 0,000. Berdasarkan analisis korelasi diperoleh nilai $r=0,628(p<0,05)$. Hal ini menunjukkan bahwa ada korelasi positif antara harga diri $(\mathrm{X})$ dengan kematangan karier $(\mathrm{Y})$. Semakin tinggi harga dirinya, maka cenderung tinggi juga kematangan karier pada mahasiswa S1 tingkat akhir. Sebaliknya semakin rendah harga dirinya maka kematangan karier mahasiswa S1 tingkat akhir cenderung rendah.

Hasil analisis data menunjukkan adanya hubungan positif antara harga diri dengan kematangan karier pada mahasiswa S1 tingkat akhir. Semakin tinggi harga diri yang dimiliki oleh mahasiswa S1 tingkat akhir, maka akan cenderung tinggi kematangan kariernya. Sebaliknya, semakin rendah harga diri yang dimiliki mahasiswa S1 tingkat akhir, maka akan cenderung rendah pula kematangan karier yang dimilikinya. Hal ini berarti hipotesis yang menyatakan bahwa ada hubungan positif antara harga diri dengan kematangan karier pada mahasiswa S1 tingkat akhir diterima.

Kematangan karier dipengaruhi oleh beberapa faktor, salah satunya harga diri (Savickas, 2001). Harga diri dapat dipahami sebagai evaluasi individu terhadap dirinya sendiri yang diekspresikan dalam sikap terhadap diri sendiri. Evaluasi ini menyatakan suatu sikap penerimaan atau penolakan dan menunjukkan seberapa besar individu percaya bahwa diirinya mampu, berarti, berhasil, berharga menurut standart dan nilai pribadinya.

Menurut Centi (2004) bahwa harga diri dipelajari dari pengalaman berhubungan dengan orang lain, pengalaman tersebut dapat terbentuk bagaimana orang lain tersebut memperlakukan diri kita, bagaimana kita menangkap pantulan tentang diri kita, dan bentuk gagasan tentang seperti apakah diri kita sebagai pribadi. Menurut Coopersmith (1987) harga diri adalah proses evaluasi terhadap diri sendiri dan proses penerimaan individu terhadap dirinya. Harga diri tersusun dari beberapa aspek yaitu keberartian diri (significance). Maslow (Alwisol, 2002) harga diri merupakan suatu kebutuhan manusia yang memerlukan pemenuhan atau pemuasan untuk dilanjutkan ke tingkat kebutuhan yang lebih tinggi. 
Kebutuhan terhadap harga diri oleh Maslow dibagi menjadi dua jenis yaitu penghargaan diri dan penghargaan dari orang lain. Jika seseorang merasa dicintai dan memiliki rasa memiliki (sense of belonging), maka mereka akan mengembangkan kebutuhan untuk penghargaan (need for esteem). Keberartian diri membuat individu merasa dirinya berarti atau tidak, baik untuk diri sendiri maupun lingkungan. Mahasiswa yang memiliki keberartian hidup yang tinggi, ia akan merasa mampu untuk merencanakan kariernya dan merasa mempunyai masa depan yang indah kedepannya. Hal tersebut berhubungan dengan aspek perencanaan karier dalam kematangan karier, karena jika mahasiswa tersebut merasa dirinya berarti maka ia akan melakukan perencanaan karier dengan baik, maka mahasiswa tersebut akan memiliki kematangan karier yang tinggi.

Harga diri juga tersusun dari kekuatan individu (power). Kekuatan individu yaitu kemampuan individu untuk mempengaruhi orang lain, serta mengontrol atau mengendalikan orang lain, disamping mengendalikan dirinya sendiri. Sementara Atwater (dalam Dariuszky, 2004) mengemukakan, sebenarnya harga diri adalah cara seseorang merasakan dirinya sendiri dimana,seseorang akan menilai dan menghargai dirinya sendiri. Bagaimana seseorang menilai tentang dirinya akan mempengaruhi perilaku dalam kehidupannya seharihari. Kekuatan juga dikaitkan dengan inisiatif. Seorang mahasiswa S1 tingkat akhir yang memiliki kekuatan individu yang tinggi, maka mahasiswa tersebut akan mampu mengontrol diri sendiri dan orang lain dengan baik untuk dapat mempersiapkan kariernya dengan baik, serta mempunyai inisiatif yang tinggi untuk mencari informasi untuk menunjang kariernya, serta mempunyai inisiatif untuk mengeksplorasi kemampuan nya dalam kegiatan-kegiatan yang mendukung kariernya.

Hal ini berhubungan dengan aspek informasi dan sumber-sumber eksplorasi dalam kematangan karier, karena mahasiwa akan mempunyai inisiatif untuk berkonsultasi dengan orang lain, mencari sumber-sumber informasi yang dibutuhkan yang berkaitan dengan pekerjaan dan berinisiatif untuk berpartisipasi aktif dalam kegiatan yang dapat menunjang kariernya, maka mahasiswa tersebut akan memiliki kematangan karier yang tinggi, karena ia dapat mengontrol dirinya sendiri dan mempunyai inisiatif yang tinggi dalam mempersiapkan masa depannya.

Kompetensi juga merupakan salah satu aspek dari harga diri. Kompetensi yaitu kemampuan untuk mendapatkan prestasi yang baik, sesuai dengan tahap usiannya. Menurut Phares (Silalahi, 2009) Kemampuan seseorang yakin bahwa kesuksesan dan kegagalan yang telah terjadi sangat dipengaruhi oleh kemampuan yang dimiliki. Menurut Rotter (Neill, 2006) dan Mearns (2009) Berusaha dan percaya untuk mencapai suatu tujuan dengan 
kemampuan, keterampilannya sendiri dan bertanggung jawab. Pendapat tersebut juga diperkuat oleh Branden (2007) yang mendefinisikan harga diri sebagai penilaian personal individu pada kompetensi dirinya, bahwa ia mampu menghadapi tantangan hidup sehingga layak untuk mendapat kebahagiaan. Mahasiswa merasa bahwa prestasi akademik dan soft skill yang dimiliki adalah hal utama yang diukur untuk menilai kompetensinya dalam menunjang kariernya kelak, maka individu tersebut akan melakukan usaha yang maksimal dengan berfikir realistis dengan prestasi yang dicapai dan dapat mencapai prestasi akademik yang tinggi dan memiliki soft skill yang tinggi serta konsisten dalam pencapaian prestasinya.

Hal tesebut berhubungan dengan aspek berorientasi pada realita dalam kematangan karier, karena individu tersebut memiliki pengetahuan yang baik akan dirinya, dapat berfikir realistis akan kemampuan dirinya serta individu tersebut menunjukan sikap yang konsisten dalam mencapai kompetensi nya. Maka mahasiswa tersebut akan memiliki kematangan karier yang tinggi karena akan berusaha sebaik-baiknya untuk mencapai pekerjaan yang diharapkannya dan meningkatkan kemampuannya.

Kebajikan yaitu ketaatan individu mengikuti standart moral dan etika yang berlaku di masyarakat. Coopersmith (Santrock, 2002) Seseorang yang taat terhadap nilai moral, etika dan agama dianggap memiliki sikap yang positif dan akhirnya membuat penilaian positif terhadap diri yang artinya seseorang telah mengembangkan harga diri yang positif pada diri sendiri. Ketaatan individu yaitu ketaatan terhadap aturan dalam masyarakat serta tidak melakukan tindakan yang menyimpang dari ketentuan yang berlaku yang akan membuat individu diterima dengan baik oleh lingkungannya, dan apabila individu mampu memberikan contoh atau dapat menjadi panutan yang baik akan diterima secara lebih baik di lingkungannya. Mahasiswa yang mentaati peraturan yang ada dalam pemenuhan syarat penerimaan kerja serta dapat mempersiapkan diri dalam penentuan kariernya dan konsisten dalam hal tersebut, ia akan semakin menjadi inspirasi yang baik bagi teman-temannya.

Hal tersebut berhubungan dengan aspek berorientasi pada realita dalam kematangan karier, karena individu tersebut dapat melakukan hal yang konsisten dalam mentaati peraturan serta memberikan contoh yang baik, sesuai realitas yang ada di sekitarnya dengan baik. Hal ini yang membuat individu tersebut memiliki kematangan karier yang tinggi, karena ia dapat menyesuaikan diri untuk mempersiapkan dirinya memasuki dunia pekerjaan dengan baik.

Berdasarkan kategori skor, subjek memiliki kematangan karier dalam kategori rendah sebanyak 0 subjek (0\%), subjek yang memiliki kematangan karier kategori sedang sebanyak 52 subjek $(51,5 \%)$ dan subjek yang memiliki kematangan karier dengan kategori tinggi 
sebanyak 49 subjek (48,5\%). Crites (Chapman, M.; Balabanov, R.; Bischoff, C; Dean, H.; Denyer, D; Jesten, B.; Johns, C.; \& Politano, C., 1994) mengemukakan bahwa individu yang memiliki kematangan karier tinggi ditandai dengan memiliki pengetahuan akan diri, pengetahuan tentang pekerjaan, kemampuan memilih pekerjaan, dan kemampuan merencanakan langkah-langkah menuju karier yang diharapkan. Dari hasil kategorisasi skor tersebut menunjukkan bahwa dalam penelitian ini sebagian besar subjek memiliki kematangan karier yang sedang, namun dalam penelitian ini tidak terdapat perbedaan yang terlalu signifikan dari yang memiliki kematangan karier yang tinggi.

Penelitian ini menunjukan bahwa mahasiswa memiliki perencanaan karier yang cukup baik, mahasiswa sudah mempersiapkan kariernya sejak awal. Mahasiswa mengeksplorasi kemampuannya dengan mengikuti kegiatan akademik maupun non akademik untuk mendukung kariernya. Mahasiswa memiliki informasi tentang karier yang akan dituju. Mahasiswa dapat mengambil keputusan, walaupun atas pertimbangan orangtuanya. Mahasiswa juga cukup dapat mengukur kemampuannya dengan pekerjaannya yang akan dicapai nantinya.

Berdasarkan kategori skor, subjek memiliki harga diri dalam kategori rendah sebanyak 0 subjek (0\%), subjek yang memiliki harga diri kategori sedang sebanyak 65 subjek $(64,4 \%)$ dan subjek yang memiliki harga diri dengan kategori tinggi sebanyak 36 subjek (35,6\%). Lutan (2003) memaparkan siswa yang memiliki harga diri tinggi atau harga diri yang sehat pada umumnya memiliki kepercayaan diri dan keyakinan yang tinggi pula untuk dapat melakukan tugas gerak yang diinstruksikan. Dari hasil kategorisasi skor tersebut menunjukkan bahwa dalam penelitian ini sebagian besar subjek memiliki harga diri yang sedang. Hal ini menunjukan bahwa mahasiswa memiliki harga diri yang cukup baik, artinya mahasiswa memiliki keberartian diri yang cukup baik dapat menyesuaikan diri di lingkungan yang baru, memiliki kekuatan diri yang cukup baik dengan dapat diterimanya ide-ide dan gagasannya oleh orang lain, memiliki kompetensi yang cukup dengan memaksimalkan kemampuan yang dimiliki untuk mencapai kesuksesan dalam kariernya, dan dapat melakukan kebajikan dengan menghormati orang-orang yang ada di sekitarnya.

Melihat hasil uraian diatas subjek yang termasuk dalam kategori harga diri yang tinggi akan cenderung untuk memiliki tingkat kematangan karier yang tinggi pula begitupun sebaliknya. Hal tersebut menunjukkan bahwa secara umum subjek penelitian ini memiliki tingkat harga diri yang sedang. Hal ini semakin memperkuat hipotesis bahwa subjek yang memiliki tingkat harga diri tinggi memiliki kematangan karier yang tinggi pula. Berdasarkan hasil koefisien determinasi $\left(\mathrm{R}^{2}\right)$ didapatkan nilai sebesar 0,394 hal ini menunjukkan bahwa 
variabel harga diri berkontribusi atau memberi sumbangan sebesar 39,4\% terhadap variabel kematangan karier. Sisanya sebesar 60,6\% dipengaruhi faktor yang lain yaitu faktor internal seperti intelegensi, bakat, minat, kepribadian, nilai dan serta faktor eksternal yaitu keluarga, sosial ekonomi, gender, teman sebaya dan lingkungan sekolah (Super dalam Savickas, 2001).

\section{KESIMPULAN}

Berdasarkan hasil analisis data dan pembahasan, maka dapat diambil kesimpulan bahwa harga diri mempunyai hubungan yang positif yang signifikan dengan kematangan karier pada mahasiswa S1 tingkat akhir. Hal ini dapat dilihat dari nilai $r=0,628(p<0,05)$. Artinya, mahasiswa S1 tingkat akhir yang memiliki harga diri yang tinggi akan memiliki kematangan karier yang tinggi pula. Sebaliknya mahasiswa S1 tingkat akhir yang memiliki harga diri yang rendah maka akan memiliki kematangan karier yang rendah pula. Terlihat dari aspek-aspek harga diri yang dapat menyebabkan munculnya kematangan karier pada mahasiswa S1 tingkat akhir, yaitu aspek keberartian diri (significant), kekuatan individu (power), kompetensi (competence), dan aspek kemampuan memberi contoh (virtue). Harga diri memberikan sumbangan efektif terhadap kematangan karier pada mahasiswa S1 tingkat akhir sebesar 39,4\%, sedangkan $60,5 \%$ sisanya berhubungan dengan faktor lain, yaitu faktor internal seperti intelegensi, bakat, minat, kepribadian, nilai dan serta faktor eksternal yaitu keluarga,sosial ekonomi, gender, teman sebaya dan lingkungan sekolah.

\section{DAFTAR PUSTAKA}

Alwisol. (2002) Psikologi Kepribadian, Malang: Penerbit Universitas Muhammdiyah Malang.

Amy. (2015). Hubungan Antara Harga Diri dengan Kematangan Karier pada Siswa kelas XI Teknik Gambar Bangunan SMK Negri 2 Depok, Sleman, Yogyakarta. Skripsi. Fakultas Bimbingan dan Konseling. Universitas Negeri Yogyakarta.

Azwar, S. (2003). Metode Penelitian. Yogyakarta: Pustaka Pelajar.

Azwar, S. (2004). Reliabilitas dan Validitas. Yogyakarta: Pustaka Pelajar.

Badan Pusat Statistik. (2012). Survei Demogrfi. No. 75/11/TH XV. Diunduh dari http://www.bps.go.id. tanggal 20 Mei 2017.

Chapman, M.; Balabanov, R.; Bischoff, C; Dean, H.; Denyer, D; Jesten, B.; Johns, C.; \& Politano, C. (1994). The Primary Program : A Framework for Teaching Education. Manual programme. Bristish Columbia Ministry of Education. 
Branden, N. (2007). 6 Pilar Penghargaan Diri. Semarang: Dahara Prize.

Centi. P. J. (2004). Mengapa Rendah Diri. Alih bahasa: A.M Hardjana. Yogyakarta: Kanisius.

Coopersmith, S. (1987). Self-esteem inventories (SEI): Self-esteem inventories. Palo Alto: Consulting Psychologist Press.

Dariuszky, G. (2004). Membangun Harga Diri. Bandung : CV. Pionir Jaya.

Deddy S. (2017). Mencari solusi rendahnya serapan tenaga kerja sarjana kita Diunduh dari https://student.cnnindonesia.com/edukasi/20171026151125-445-251298 tanggal 20 Mei 2017.

Gonzalez, M. A. (2008). Career Marturity : A Priority for secondary education. Electronic Journal of Reaserch in Educational Pshcology, 6(3), 749-772.

Hervy, P. (2015). Hubungan Antara Efikasi Diri dengan Kematangan Karier pada Mahasiswa S1 Tingkat Akhir di beberapa Perguruan Tinggi di Yogyakarta. Skripsi. Universitas Sanata Dharma.

Hurlock, E. B. 1990. Psikologi Perkembangan: Suatu Pendekatan Sepanjang Rentang Kehidupan. Alih Bahasa: Soedjarwo dan Iswidayanti. Jakarta: Erlangga.

Lutan, R (2003). Positive-Self-Esteem. Diunduh dari http:/www.positive-selfesteem-selfesteem-yang-sehat.pdf.com tanggal 29 Agustus 2017,.

McIntosh, P.I. (2000). Life career Development : Implications for school counselors. Education, 120(4), 621-625. http://search.proquest.com/openview/ 5df33a2135ad240b9fab8e5369fe1b81/1?pq-origsite=gscholar.

Mearns, J. (2009). The Social Learning Theory of Julian Rotter. Diunduh dari http://psych.fullerton.edu/jmearns/rotter.htm tanggal 22 Mei 2011.

Neill, J.T. (2006). Locus of Control - a Class Tutorial. (Electronic version). Diunduh dari http://www.wilderdom.com /personality/locus of control.html) tanggal 20 Juli 2017.

Priyatno, D. (2010). Paham Analisis Statistik Data dengan SPSS. Yogyakarta: MediaKom.

Safitri, R. M. (2014). Modul Praktikum Analisis Data. Yogyakarta: Universitas Mercu Buana Yogyakarta.

Santrock, J.W (2002) Life Span Development: Perkembangan Masa Hidup. Jakarta : Penerbit Erlangga.

Sugiyono. (2010). Metode Penelitian Pendidikan: Pendekatan Kuantitatif, Kualitatif, dan $R \& D$. Bandung : CV Alfabeta.

Savickas, M.L (2001). A Developmental Perspective on Vocational Behaviour Career Pattern, Salience, and Themes. International Journal for Educational and Vocational Guidance, 1, 49-57. 
Silalahi, V. (2009). Hubungan Locus of Control dengan Perilaku Kesehatan Pada Masyarakat Perdesaan. Skripsi. Fakultas Psikologi Universitas Sumatera Utara.

Yulianti, K.D., Hardjono, \& Nugroho, A.A. (2013). Hubungan antara Harga diri dan Motivasi Berprestasi dengan Kematangan Karier pada Siswa Kelas XI SMK N 3 Surakarta. Jurnal Ilmiah Psikologi Candrajiwa, 2(1), 1-11. 